Jarosław FILIPIAK ${ }^{1}$, Antoni PRZYBYE ${ }^{2}$, Jacek SADOWSKI ${ }^{3}$, Magdalena PLUST ${ }^{3}$, Rajmund TRZEBIATOWSKI ${ }^{3}$

Fish aquaculture

\title{
EFFECTS OF DIFFERENT DIETARY LIPID LEVELS IN EXTRUDED \\ FOOD ON THE GROWTH OF 1+-OLD CARP (CYPRINUS CARPIO) CULTURED IN COOLING WATER
}

WPL YW RÓŻNEJ ZAWARTOŚCI LIPIDÓW W PASZACH EKSTRUDOWANYCH NA WZROST JEDNOROCZNYCH KARPI (CYPRINUS CARPIO L.) W WODZIE POCHLODNICZEJ

\footnotetext{
${ }^{1}$ Department of Fisheries Management in Inland Waters, Agricultural University of Szczecin, Poland

${ }^{2}$ Department of Inland Fishery and Aquaculture, Agricultural University of Pozmań, Poland

${ }^{3}$ Department of Aquaculture, Agricultural University of Szczecin, Poland
}

Carp of the initial individual weight of $1020 \mathrm{~g}(+55 \mathrm{~g})$ were fed in cages with four kinds of extruded, isoprotein feeds differing in the lipid content $7.5 \%$ in feed $\mathrm{A}, 11.6 \%$ in feed B, $15.3 \%$ in foed C, and $19.5 \%$ in feed D). The main source of lipids was a poultry fat. After the completion of the 52-daylong experiment the following values of the SGR and FCR indices were achieved (respectively): $\mathrm{A}-1.59$ and $1.58, \mathrm{~B}-1.47$ and $1.42, C-1.59$ and 1.30 , and $\mathrm{D}-1.59$ and 1.29 . The stage results, calculated every 7 days, as well as, the abovementioned final values $f$ FCR and SGR indicated, that throughout the entire period of study, the most favourable results of rearing were achieved while feeding the carp with the feed containing $15.3 \%$ of lipids, regardless of the water temperature, which ranged from $22.0-30.0^{\circ} \mathrm{C}$ at the time of the experiment.

\section{INTRODUCTION}

In the intensive culture of carp and other fishes an important role of one of the growth stimulators is played by the lipids present in the diet. Like in the case of the proteins, the 
level of this stimulation depends among other factors, on the amount and origin of the lipids. The above factors are important, because of the exogenous fatty acids present in the lipids and the generally understood "quality" of fats used for manufacturing individual feeds (Viola et al. 1981; Kaushik 1995). At the same time, the lipids present in the carp feed compared with proteins and carbohydrates, constitute respectively 1.9 and 2.4 times more effective source of metabolic energy (Smith 1971; Chiou and Ogino 1975; Austreng 1978). The studies conducted on the carp fry demonstrated, that in the cooling water temperature within $25-30^{\circ} \mathrm{C}$ the highest body-weight increment was achieved with the feed containing $15 \%$ of fat in the pellet feed (Filipiak 1995). The lack, in the accessible literature, of the data pertaining to the effects of different lipid content in the extruded feeds on the growth and other parameters of cooling water culture of one-year-old carp was a reason for conducting the present experiment.

\section{MATERIAL AND METHODS}

The feeding study was conducted from 22 July to 12 September 1996 in the Fisheries Experimental Station (FES). The station, located near the "Dolna Odra" power plant at Nowe Czarnowo, is owned by the Department of Aquaculture, Agricultural University of Szczecin. The experimental material consisted of 360 carp of the initial average body weight of $1020 \mathrm{~g} \mathrm{(} \pm 55 \mathrm{~g})$ which at the time of the experiment were kept in 12 cages $(0.75 \times 2.0 \times$ $0.8 \mathrm{~m}$ ). Each cage had the usable volume of $1 \mathrm{~m}^{3}$, hosting $30 \mathrm{fish}$. On the very first day after arriving from a private fish-farmer from Gryfino, the individual weight of the fish was $5.0 \mathrm{~g}$ $( \pm 1.0 \mathrm{~g})$.

During the experiment the carp were fed daily with four feeds differing in the lipid content. The feeds were identified by the symbols A, B, C, and D. Each of the feeds was tested in three repetitions (Tab. 1). The feeds were manufactured using an extrusion method at the Experimental Facility of the Division of Food Technology and Aquaculture of the University of Agriculture at Poznan. The diameter of the pellets was $8 \mathrm{~mm}$. All fish were fed with identical rations of each feed, which were calculated in relation to the metabolic weight of the fish (Filipiak et al. 1995a). The daily rations were $3.0 \%$ within 22 July and 15 August, $2.5 \%$ within 16 and 21 August, and $2.0 \% \mathrm{~W}^{0}{ }^{8}$-from 22 September to the end of the experiment.

On the beginning and at the end of each experiment, a total of 4 fish was sampled from each variant. They were subjected to complete homogenisation and examined for the content of: dry mass (drying for 12 hours at $105^{\circ} \mathrm{C}$ ), crude protein (Kjeltec 1026), lipids (Soxhlet method; 12 hours of extraction with ethyl ether), ash (combustion at $550^{\circ} \mathrm{C}$ for 12 hours). Chemical analyses of the feeds were conducted using the same methods, however the content of $\mathrm{N}$-free extract was determined from the difference between the dry mass and 
the sum of the remaining components, including the fiber. The content of the latter component was determined using a standard of acid and base hydrolysis. The level of the gross energy in the feeds was determined from the individual components using the following conversion coefficients: $39.53 \mathrm{~kJ} / \mathrm{g}$ (lipids), $23.63 \mathrm{~kJ} / \mathrm{g}$ (crude protein), and $17.15 \mathrm{~kJ} / \mathrm{g}$ (carbohydrates) (Jobling 1994). The metabolic energy was calculated adopting the method of Jauncey (1981), who in turn followed Smith (1971) assuming the value of 4.5 for protein, 8.51 for fat (after Austreng 1978) and $3.49 \mathrm{kcal} / \mathrm{g}$ for N-free extract (after Chiou and Ogino 1975).

To asses the dynamics of the changes in the basic rearing parameters and to adjust the amounts of the administered feed to the current needs, the fish were weighed in each cage every 7 days. The results of the control weighing the stage values of the following coefficients were determined: FCR (Food Conversion Ratio), SGR (Specific Growth Rate), aNPU (apparent Net Protein Utilisation), ER (Energy Retained), and aLR (apparent Lipids Retained). To determine the significance of the differences between the variants all values of the above-mentioned rearing coefficients were subjected to statistical analysis (LSD test, $\mathrm{P}=0.05)$.

The temperature, oxygen content, and $\mathrm{pH}$ of the cooling water were constantly monitored (every 60 minutes) using an automated recorder. The mean diel values and the ranges of changes of the analysed physical-chemical parameters were shown on Fig. 1.

\section{RESULTS AND DISCUSSION}

Description of the experimental feeds

Specifically designed formula of the feeds tested, guarantied almost equal content of crude protein which exceeded slightly (about 3-4\%) the level of the protein demand recommended by Filipiak (1995) in the rearing process of two-year-old carp in cooling water. The feeds differed in the lipid content. The alternative A contained 5.5\%, B-11.6\%, $\mathrm{C}-15.3 \%$, and $\mathrm{D}-19.5 \%$ of this component (Tab. 1). The variable lipid content was achieved through spraying the pellets with variable amount of semi-liquid poultry fat $(4.0 \%$ in $\mathrm{B}, 8 \%$ in $\mathrm{C}$, and $12 \%$ in $\mathrm{D}$ ). The structural lipid content amounting to $7.4 \%$ was a result of the fat present in the respective components: fishmeal $(9.9 \%)$, poultry slaughter byproduct meal (15.6\%), lupine (4.2\%), and rapeseed lecithin. The latter component responsible, among other things, for enhancing emulsification and nutritive absorption of the lipid fraction, was added to each feed in the amounts optimal for carp cultured in cooling water in summer season (Sadowski et al. 1997). 

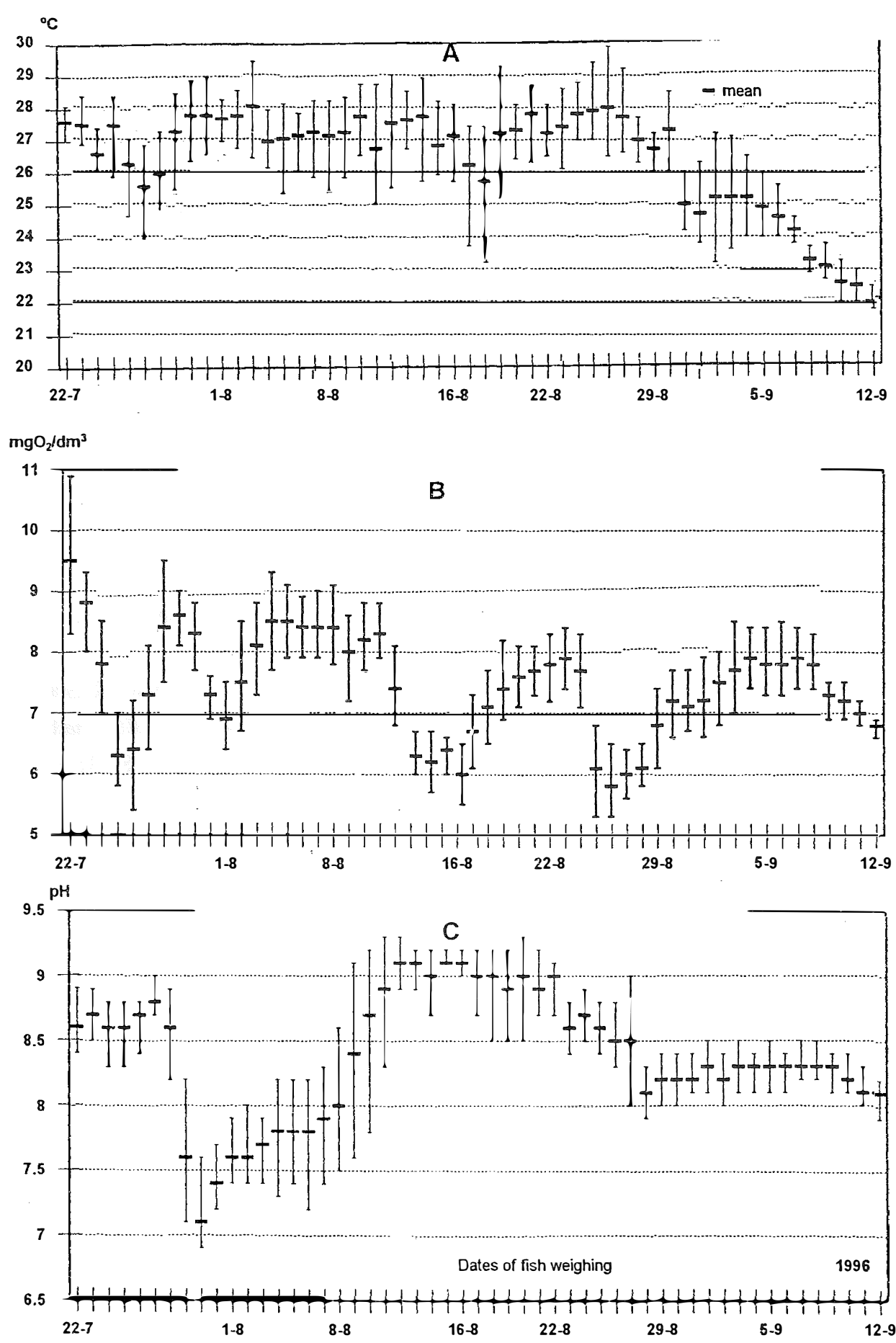

Fig, 1. Diel changes of temperature (A), oxygen contents (B) and $\mathrm{pH}(\mathrm{C})$ in cooling water during the experiment 
Table 1

Components and chemical composition (\%) of diets used for feeding carp

\begin{tabular}{|l|r|r|r|r|}
\hline \multirow{2}{*}{ Components } & \multicolumn{4}{c|}{ Feed variants } \\
\cline { 2 - 5 } & \multicolumn{1}{|c|}{$\mathrm{A}$} & $\mathrm{B}$ & $\mathrm{C}$ & $\mathrm{D}$ \\
\hline Fish meal & 33.0 & 33.0 & 33.0 & 33.0 \\
Poultry by product meal & 21.0 & 21.0 & 21.0 & 21.0 \\
Lupine crude & 11.0 & 11.0 & 11.0 & 11.0 \\
Wheat meal & 22.7 & 18.7 & 14.7 & 10.7 \\
Wheat bran & 10.0 & 10.0 & 10.0 & 10.0 \\
Polfamix W* (commercial vitamin mixture) & 1.5 & 1.5 & 1.5 & 1.5 \\
Witasol $\mathrm{AD}_{3} \mathrm{E}$ & 0.1 & 0.1 & 0.1 & 0.1 \\
Rapeseed lecithine & 0.5 & 0.5 & 0.5 & 0.5 \\
Choline chloride & 0.2 & 0.2 & 0.2 & 0.2 \\
Poultry fat & - & 4.0 & 8.0 & 12.0 \\
\hline \multicolumn{1}{|c}{ Chemical composition } & & & & \\
\hline Dry matter & 91.8 & 91.9 & 92.0 & 92.1 \\
Crude protein (P) & 41.8 & 41.4 & 40.9 & 40.5 \\
Lipids & 7.5 & 11.6 & 15.3 & 19.5 \\
Ash & 9.9 & 9.9 & 9.8 & 9.8 \\
Fiber & 4.3 & 4.3 & 4.2 & 4.1 \\
N-free extract & 28.3 & 24.7 & 21.8 & 18.2 \\
Gross energy (E) (KJ/g) & 18.4 & 19.3 & 20.2 & 21.1 \\
Metabolic Energy (KJ/g) & 14.7 & 15.5 & 16.3 & 17.2 \\
P/E (mg/KJ) & 22.7 & 21.4 & 20.3 & 19.2 \\
\hline
\end{tabular}

* In $1 \mathrm{~kg}$-Vitamin: A - $10000 \mathrm{IU}, \mathrm{D}_{3}-2000 \mathrm{IU}, \mathrm{E}-1.5 \mathrm{~g}, \mathrm{~K}-0.2 \mathrm{~g}, \mathrm{~B}_{1}-0.05 \mathrm{~g}, \mathrm{~B}_{2}-0.4 \mathrm{~g}$, $\mathrm{B}_{12}-0.001 \mathrm{~g}$, nicotinic acid $-2,5 \mathrm{~g}$, pantothenian $\mathrm{Ca}-1.0 \mathrm{~g}$, choline chloride $-7.5 \mathrm{~g}$, folic acid $-0.1 \mathrm{~g}$, methionine $-150 \mathrm{~g}$, lysine $-150 \mathrm{~g}, \mathrm{Fe}-2.5 \mathrm{~g}, \mathrm{Mn}-6.5 \mathrm{~g}, \mathrm{Cu}-0.8 \mathrm{~g}$, $\mathrm{Co}-0.04 \mathrm{~g}, \mathrm{Zn}-4.0 \mathrm{~g}, \mathrm{~J}-0.08 \mathrm{~g}$.

\section{Environmental conditions}

Throughout the entire experiment the values of the studied physical-chemical parameters of the cooling water were typical for the summer season and they did not differ from those recorded in earlier years (Filipiak et al. 1995b). The average diel water temperature was within $22.0-28.1^{\circ} \mathrm{C}$. The oxygen content changed within 6.0 to $9.5 \mathrm{mg} / \mathrm{dm}^{3}$ and $\mathrm{pH}$ was from 7.1 to 9.2. (Fig. 1).

Rearing results

Based on the weakly weighing the experiment was divided into 7 stages. For each stage and for each variant the rearing coefficients were calculated and they were presented in Tab 2. In the first three weeks the daily ration of the feeds calculated in relation to the metabolic weight of the fish was $3 \% \mathrm{~W}^{0.8}$, while in the last three weeks- $2 \% \mathrm{~W}^{0.8}$. The prevailing temperature of the cooling water oscillated around $26-28^{\circ} \mathrm{C}$, whereas in the last two weeks it declined from 25 to $22^{\circ} \mathrm{C}$. Despite the differences in the amount of the feed ad- 
ministered and the changes in the temperature of the water-the most favourable values of the FCR and SGR coefficients in all stages of the study, were achieved in the alternatives $\mathrm{C}$ and $\mathrm{D}$. The tested feeds in the latter alternatives contained $15.3 \%$ and $19.5 \%$ of lipids respectively. Usage of lower fat-content feeds $(11.6 \%-\mathrm{A}$ and $7.5 \%-\mathrm{B})$ led, in all stages of the experiment not only to unfavourable high consumption of feed related to a unit of fish weight increment, but it also had an effect on a distinct, statistically significant, limitation of the growth rate of carp, described by the SGR coefficient. It must be emphasised that at each stage of the study no statistically significant differences were observed between the SGR values for $\mathrm{C}$ and $\mathrm{D}$ alternatives. In the final result of the 52-day-long feeding experiment the increment of the mean individual weight of the carp was identical for the two mentioned above alternatives and it amounted to $128.8 \%$ (for comparison, it reached $101.4 \%$ in alternative $\mathrm{A}$ and $115.1 \%$ in alternative $\mathrm{B})$. Alternatives $\mathrm{C}$ and $\mathrm{D}$ also yielded the highest and similar values of the SGR coefficient (Tab. 3). It means that for maximising the growth rate of carp within 1000-2300 $\mathrm{g}$ it was sufficient to use a feed containing $15.3 \%$ of lipids, which was similar as the value recommended by Watanabe et al. (1987) and Filipiak (1995) in feeding fry and 2-year-old carp.

Table 2

Mean individual weight of carp, Specific Growth Rate (SGR) and Food Conversion Ratio (FCR) in each part of experiment

\begin{tabular}{|c|c|c|c|c|c|c|c|c|}
\hline \multirow{3}{*}{$\begin{array}{l}\text { Variants } \\
\text { (\% lipids } \\
\text { in food) }\end{array}$} & \multicolumn{8}{|c|}{ Dates of fish weighings } \\
\hline & $22 \mathrm{Jul}$. & $1 \mathrm{Aug}$. & 8 Aug. & 16 Aug. & 22 Aug. & 29 Aug. & 5 Sept & 12 Sept. \\
\hline & \multicolumn{8}{|c|}{ mean individual weight $(\mathrm{g})$} \\
\hline $\mathrm{A}(7.5)$ & 1027 & 1219 & 1377 & 1532 & 1633 & 1763 & 1907 & 2069 \\
\hline $\mathrm{B}(11.6)$ & 1018 & 1214 & 1386 & 1564 & 1681 & 1832 & 2002 & 2190 \\
\hline $\mathrm{C}(15.3)$ & 1017 & 1229 & 1413 & 1611 & 1748 & 1919 & 2113 & 2327 \\
\hline $\mathrm{D}(19.5)$ & 1029 & 1242 & 1428 & 1629 & 1769 & 1942 & 2139 & 2354 \\
\hline \multicolumn{9}{|c|}{ SGR (\%/day) } \\
\hline A & - & $1.72^{\mathrm{c}}$ & $1.73^{\mathrm{c}}$ & $1.33^{\mathrm{c}}$ & $1.07^{\mathrm{c}}$ & $1.09^{c}$ & $1.12^{\mathrm{c}}$ & $1.16^{\mathrm{c}}$ \\
\hline B & - & $1.77^{\mathrm{b}}$ & $1.89^{\mathrm{b}}$ & $1.52^{\mathrm{b}}$ & $1.19^{\mathrm{b}}$ & $1.23^{\mathrm{b}}$ & $1.26^{\mathrm{b}}$ & $1.28^{\mathrm{b}}$ \\
\hline $\mathrm{C}$ & - & $1.89^{\mathrm{a}}$ & $2.00^{\mathrm{a}}$ & $1.64^{\mathrm{a}}$ & $1.36^{\mathrm{a}}$ & $1.33^{\mathrm{a}}$ & $1.38^{\mathrm{a}}$ & $1.37^{\mathrm{a}}$ \\
\hline $\mathrm{D}$ & - & $1.88^{\mathrm{a}}$ & $2.00^{\mathrm{a}}$ & $1.64^{\mathrm{a}}$ & $1.37^{\mathrm{a}}$ & $1.34^{\mathrm{a}}$ & $1.38^{\mathrm{a}}$ & $1.37^{\mathrm{a}}$ \\
\hline & & $\mathrm{SE}$ & 0.04 & 0.03 & 0.02 & 0.02 & 0.01 & 0.02 \\
\hline \multicolumn{9}{|c|}{ FCR } \\
\hline A & - & $1.59^{c}$ & $1.57^{\mathrm{c}}$ & $1.67^{\mathrm{c}}$ & $1.66^{\mathrm{c}}$ & $1.60^{c}$ & $1.54^{\mathrm{c}}$ & $1.45^{\mathrm{c}}$ \\
\hline B & - & $1.55^{\mathrm{b}}$ & $1.43^{\mathrm{b}}$ & $1.48^{\mathrm{b}}$ & $1.47^{b}$ & $1.40^{\mathrm{b}}$ & $1.34^{\mathrm{b}}$ & $1.30^{\mathrm{b}}$ \\
\hline $\mathrm{C}$ & - & $1.43^{\mathrm{a}}$ & $1.34^{\mathrm{a}}$ & $1.33^{\mathrm{a}}$ & $1.28^{\mathrm{a}}$ & $1.28^{\mathrm{a}}$ & $1.21^{\mathrm{a}}$ & $1.19^{\mathrm{a}}$ \\
\hline $\mathrm{D}$ & - & $1.44^{\mathrm{a}}$ & $1.34^{\mathrm{a}}$ & $1.33^{\mathrm{a}}$ & $1.27^{\mathrm{a}}$ & $1.28^{\mathrm{a}}$ & $1.21^{\mathrm{a}}$ & $1.20^{\mathrm{a}}$ \\
\hline \multicolumn{3}{|r|}{ SE } & 0.02 & 0.01 & 0.02 & 0.01 & 0.01 & 0.02 \\
\hline $\begin{array}{c}\text { Daily food } \\
\text { ration }\left(\% W^{0.8}\right)\end{array}$ & - & 3.0 & 3.0 & 3.0 & 2.5 & 2.0 & 2.0 & 2.0 \\
\hline
\end{tabular}


Specific Growth Rate (SGR), Food Conversion Ratio (FCR), apparent Net Protein Utilization (aNPU), apparent Lipid Retained (LR) and Energy Retained (ER) of carp fed different level lipids in food after 52 days of experiment

\begin{tabular}{|c|c|c|c|c|c|}
\hline $\begin{array}{c}\text { Variants (\% lipids } \\
\text { in food) }\end{array}$ & $\begin{array}{c}\mathrm{SGR}^{1} \\
(\% / \text { day })\end{array}$ & $\mathrm{FCR}^{2}$ & $\begin{array}{c}\mathrm{aNPU} \\
(\%)\end{array}$ & $\begin{array}{c}\mathrm{aLR}^{4} \\
(\%)\end{array}$ & $\begin{array}{c}\mathrm{ER}^{5} \\
(\%)\end{array}$ \\
\hline A (7.5) & $1.35^{\mathrm{c}}$ & $1.58^{\mathrm{c}}$ & $24.5^{\mathrm{c}}$ & $99.7^{\mathrm{a}}$ & $29.2^{\mathrm{d}}$ \\
B (11.6) & $1.47^{\mathrm{b}}$ & $1.42^{\mathrm{b}}$ & $29.2^{\mathrm{b}}$ & $71.6^{\mathrm{b}}$ & $38.4^{\mathrm{c}}$ \\
C (15.3) & $1.59^{\mathrm{a}}$ & $1.30^{\mathrm{a}}$ & $32.0^{\mathrm{a}}$ & $59.7^{\mathrm{c}}$ & $46.7^{\mathrm{b}}$ \\
D (19.5) & $1.59^{\mathrm{a}}$ & $1.30^{\mathrm{a}}$ & $32.3^{\mathrm{a}}$ & $46.8^{\mathrm{d}}$ & $53.1^{\mathrm{a}}$ \\
\hline SE & 0.02 & 0.01 & 0.19 & 0.03 & 0.19 \\
\hline
\end{tabular}

${ }^{1}$ - defined as a different between $\ln$ of final and initial individual weight of fish divided by time $\times 100$,

${ }^{2}$ - total food ration per unit of fish weight gain,

3 - amount of crude protein retained per unit of crude protein intake $\times 100$,

${ }^{4}$ - amount of lipids retained per unit of lipids intake $\times 100$,

5 - amount of gross energy retained per unit of gross energy intake $\times 100$

In the general perception, effective usage of individual nutritive components of feed mixtures for fish are dependent on properly balanced energy and the energetic homeostasis of an organism is in large extent dependent on lipid transformation (Przybył 1996). It is evident from the literature data summarised by Jobling (1994) and Kaushik (1995) that the optimal level of energetic demand of carp increases, among other factors, along with the increase of their unit weight and the water temperature. Taking into account the high temperatures of the cooling water discharged from the "Dolna Odra" power plant, the growth maximising of those fish was possible only through usage of feed characterised by a sufficiently high energy level. Therefore the feed used in alternative $\mathrm{C}$ was considered the most advantageous among the all feeds tested. It should be emphasised that the metabolic energy content in the feed $\mathrm{C}$ was only by $0.33 \mathrm{~kJ} / \mathrm{g}$ higher than the amount recommended by Jauncey (1981) for feeding carp fry cultured in water of the temperature $28^{\circ} \mathrm{C}$. The reason for less favourable results of rearing in alternatives A and B were probably not only insufficient amount of metabolic energy used in those feeds but also too high, as for the needs of carp, protein-energy factor (P/E). According to Watanabe et al. (1987) and Takeuchi et al. (1989) the above-mentioned parameter should not exceed the range of $18-20 \mathrm{mg} / \mathrm{kJ}$.

The other factor, which might have influenced the "superiority" of the feed used in alternative $\mathrm{C}$ was the fact that the $12 \%$ addition of the poultry fat, most probably, in the respect of its quantity, was an appropriate source of -important for the carp growth - certain exogenous fatty acids (EFA). The results of Scott et al. (1978) and Viola and Amidan (1978) indicate that poultry fat constitutes a substantially higher (16-23 times) source of 
linolic acid (18:2 n-6) than for instance - fish oil. It was one of the reasons why this component was added to the feeds in the studies conducted by Viola and Amidan (1980) on a tilapia hybrid (Sarotherodon aureus $\times$ S. niloticus), eel (Anguilla anguilla) (Degani 1986; Gallager and Degani 1989), and also on the fry and two-year-old carp (Viola et al. 1981, 1982; Filipiak 1989, 1995; Filipiak and Trzebiatowski 1992). Relatively low content of poultry fat in the feeds of alternatives A and B was a factor influencing unfavourably low level of metabolic energy. On the other hand it can be concluded, that in a limited degree it fulfils the demand of carp for EFA. As a result alternatives A and B were characterised by relatively high values of FCR coefficient, slower fish growth, and in the consequence also by low coefficients of protein retention (aNPU) and energy retention (ER). The limited values of those latter parameters were substantially influenced by distinctly lower value of the crude protein and also fat in the bodies of carp of the alternatives A and B compared to alternatives $\mathrm{C}$ and $\mathrm{D}$ (Tab. 4). It is worth to mention, that along with the growth of the amount of lipids in the feeds tested, the levels of fat in the fish body increased, which means that the level of the processes of re-synthesis and accumulation of fat by carp in a significant way was dependent upon the amounts of those components provided in the diet. A similar relationship was recorded also in the fry of carp fed with feeds of variable content of fish oil (Schwarz et al. 1983; Zeitler et al. 1983; Murai et al. 1985) and poultry fat (Filipiak 1995).

Table 4

Chemical body composition (\%)* of carp at the start and the end of experiment

\begin{tabular}{|c|c|c|c|c|}
\hline $\begin{array}{c}\text { Variants } \\
\text { (\% lipids in food) }\end{array}$ & Dry matter & Crude protein & Lipids & Ash \\
\hline \multicolumn{5}{|c|}{ Start of experiment } \\
\hline & 31.0 & 16.5 & 12.2 & 2.2 \\
\hline \multicolumn{5}{|c|}{ After 52 days of experiment } \\
\hline A (7.5) & $30.1^{d}$ & $16.1^{b}$ & $12.0^{\mathrm{d}}$ & $2.1^{\mathrm{a}}$ \\
\hline $\mathrm{B}(11.6)$ & $32.3^{\mathrm{c}}$ & $16.7^{\mathrm{a}}$ & $14.4^{\mathrm{c}}$ & $2.2^{\mathrm{a}}$ \\
\hline $\mathrm{C}(15.3)$ & $35.8^{\mathrm{b}}$ & $16.6^{\mathrm{a}}$ & $17.0^{\mathrm{b}}$ & $2.1^{\mathrm{a}}$ \\
\hline $\mathrm{D}(19.5)$ & $39.0^{\mathrm{a}}$ & $16.6^{\mathrm{a}}$ & $20.3^{\mathrm{a}}$ & $2.1^{\mathrm{a}}$ \\
\hline SE & 0.09 & 0.09 & $0 . \overline{16}$ & 0.05 \\
\hline
\end{tabular}

* in wet weight

High level of lipids, reaching $20.3 \%$, observed in alternative D indicates a great potential of those fish to deposit unused metabolic energy of the feed in a form of reserve fat. Complete lack of disease symptoms in the fish of this alternative (they were not present in the remaining alternatives either) proves a substantial physiological plasticity of carp, enable in relatively high water temperature utilise high-fat feeds in a degree not-threatening their health. This regularity is confirmed also by the results of the recent study of Filipiak et al. 
(1998) indicating substantial suitability of the high-energy, extruded trout feeds in the intensive market-size carp culture in cooling waters. Those feeds ensure 100-\% survival and very low feed rates (1.1-1.3) and substantial weight increments of the fish reaching $1.5-2 \%$ daily.

The experiment described above indirectly confirms the existence in several-monthold market carp-ill known adaptive physiological processes enabling utilisation in intensive growth of those fish — high-energy extruded feeds of a substantial 15-20\% content of lipids, originating from poultry fat.

\section{CONCLUSIONS}

1. The most favourable SGR and FCR indices in the rearing process of one-year-old market carp in the water of the temperature of $22-30^{\circ} \mathrm{C}$ can be achieved using an extruded highprotein feed containing ca. $15 \%$ of lipids provided chiefly by poultry fat.

2. Increase from 7.5 to $19.5 \%$ of the lipid content in high-protein extruded carp feeds had a significant effect on the increase of energy retention coefficient (RE) and the level of fat in their body, whereas in a lower degree it had effect on protein retention factor (aNPU).

\section{ACKNOWLEDGEMENTS}

The present research work was carried out in the frames of the project No. $5 \mathrm{~S} 311$ 00105 financed, in the years of 1993-1995, by the State Committee for Scientific Research.

\section{REFERENCES}

Austreng E., 1978: Digestibility determination in fish using chromic oxide marking and analysis of contents of different segments of the gastrointestinal tract. Aquaculture, 13: 256-272.

Chiou J.Y., Ch. Ogino, 1975: Digestibility of starch in carp, Bull. Jap. Soc. Sci. Fish., 41, 4: 465466.

Degani G., 1986: Dietary effect of lipid source, lipid level and temperature on growth of glass eel (Anguilla anguilla). Aquaculture, 56, 3/4: 207-214.

Filipiak J., 1989: Wykorzystanie mączki mięsno-kostnej i tłuszczu drobiowego w żywieniu narybku karpia w warunkach wody pochłodniczej [Utilization of poultry by product meal and poultry fat on feeding young carp reared in cooling water]. Gospod. Ryb. 4: 14-16 (In Polish).

Filipiak J., 1995: Wybrane aspekty żywienia karpi (Cyprinus carpio L.) w sadzowym chowie w wodzie pochłodniczej [Selected aspects of feeding the carp (Cyprinus carpio L.) kept in heated-water cage cultures]. Zesz. Nauk. AR Szczecin, ser. Rozprawy, nr 167 (DSc. Thesis). (In Polish, with English abstract).

Filipiak J., R. Trzebiatowski, 1992: Wpływ mieszanek paszowych wzbogaconych o różne rodzaje tłuszczów na podstawowe wskaźniki chowu narybku karpi w wodzie pochłodniczej [Effect of feed mixtures enriched with various fats on basic indices of young carp reared in cooling waters]. Zesz. Nauk. AR Wrocław, 218:81-88. (In Polish, with English abstract). 
Filipiak J., J. Sadowski, R. Trzebiatowski, 1995a: Comparison of the effects of cage rearing of African catfish (Clarias gariepinus) and Nile tilapia (Oerochromis nilotica) in cooling water. Arch. Ryb. Pol., 3: 95-105.

Filipiak J., J. Sadowski, R. Trzebiatowski, 1995b: Rybactwo - przewodnik do ćwiczeń cz. II. Wybrane elementy chowu ryb [Fisheries-selected aspects of fish culture]. Wyd. Akademii Rolniczej w Szczecinie. (In Polish.).

Filipiak J., J. Sadowski, R. Trzebiatowski, 1998: Determination of usefulness of select commercial feeds in rearing carp. Fol. Univ. Agric. Stetinensis, ser. Piscaria, 24: 5-13.

Gallager M.L., G. Degani, 1989: Poultry meal and poultry oil as sources of protein and lipid in the diet of European eels (Anguilla anguilla). Aquaculture, 73: 177-187.

Jauncey K., 1981: The effect of varying dietary composition of mirror carp (Cyprinus carpio) maintained in thermal effluents and laboratory recycling systems. Proc. World Symp. on Aquaculture in Heated Effluents and Recirculation System, Stavanger 27-30 May 1980, Berlin 1981: 249-261.

Jobling M., 1994: Fish bioenergetics. Chapman \& Hall, London.

Kaushik S.J., 1995: Nutrient requirements supply and utilization in the context of carp culture. Aquaculture, 129: 225-241.

Murai T., T. Akiyama, T. Takeuchi, T. Watanabe, T. Nose, 1985: Effect of dietary protein and lipid levels of performance and carcass composition of fingerling carp. Bull. Jap. Soc. Sci. Fish., 51: 605-608.

Przybyl A., 1996: Rola i znaczenie frakcji tłuszczowej mieszanek paszowych w żywieniu ryb [Importance of lipid fraction in pelets in fish feeding]. Przegl. Rybacki, 6: 45-50 (In Polish).

Sadowski J., J. Filipiak, R. Trzebiatowski, 1997: Impact of different levels of rapessed lecithin in diet on effects of rearing of carp (Cyprinus carpio L.) in cooling water. Zesz. Nauk. AR Szczecin, 179: 35-42.

Scot M.L., M.C. Nesheim, R. J. Young, 1978: Żywienie kur [Nutrition of the chicken]. PWRiL, Warszawa.

Schwarz F.J., M.H. Zeitler, M. Kirchgessmer, 1983: Wachsum und Nahrstoffverdaulichkeit beim Karpfen, (Cyprinus carpio L.) mit unterschiedlicher Protein- und Energieversorgung. 2. Gewichtsentwicklung, Futterwertung, Protein- und Energieaufwand. Z. Tierphysiol. Tierernahr. Futtermittelkd., 49: 88-98.

Smight R.R, 1971, A method for measuring the digestibility and metabolisable energy of fish feeds. Progr. Fish Cult., 33: 132-134.

Takeuchi T., T. Watanabe, S. Satoh, R.C. Martino, T. Ida, M. Yaguchi, 1989: Suitable levels of protein and digestible energy in practical carp diets. Nippon Suisan Gakkaishi, 55: 521-527.

Watanabe T., T. Takeuchi, S. Satoh, T. Ida, M. Yaguchi, 1987: Development of low proteinhigh energy diets for practical carp culture with special reference ro reduction of total nitrogen excretion. Nippon Suisan Gakkaishi, 53, 8: 1413-1423.

Viola S., G. Amidan, 1978: The effects of different dietary oil supplements on the composition of carp's body fat. Bamidgeh, 30, 4: 104-109.

Viola S, G. Amidan, 1980: Observation on the accumulation of fat in carp and Sarotherodon (Tilapia) fed oil-coated pellets. Bamidgeh, 32: 34-40.

Viola S., U. Rappaport, Y. Arieli, G. Amidan, S. Mokady, 1982: The effect of oil-coated pellets on carp (Cyprinus carpio) in intensive culture. 1981/1982 Aquaculture, 26: 346-65.

Zeitler H.M., M. Kirchgessner, F.J. Schwarz, 1983: Effect of different protein and energy supplies on carcass composition of carp (Cyprinus carpio L.). Aquaculture, 36: 37-48. 
Jarosław FILIPIAK, Antoni PRZYBYZ, Jacek SADOWSKI, Magdalena PLUST, Rajmund TRZEBIATOWSKI,

\section{WPŁYW RÓŻNEJ ZAWARTOŚCI LIPIDÓW W PASZACH EKSTRUDOWANYCH NA WZROST JEDNOROCZNYCH KARPI (CYPRINUS CARPIO L.) W WODZIE POCHŁODNICZEJ}

\section{STRESZCZENIE}

Karpie o masie 1020 g/szt. ( \pm 55 g), obsadzone po 30 sztuk do 12 sadzów, przez 52 dni żywiono czterema ekstrudowanymi paszami różniącymi się zawartością lipidów (wariant $\mathrm{A}-7,5$; B - 11,6; C - 15,3 i D - 19,5\%) przy zbliżonym poziomie białka ogólnego (od 41,8\% w wariancie A do $40,5 \%$ w wariancie D). Główne źródło lipidów w paszach stanowił tłuszcz drobiowy. Po zakończeniu badań uzyskano następujące wartości wskaźników SGR oraz FCR, odpowiednio: wariant A - 1,35 i 1,58; B - 1,47 i 1,42; C - 1,59 i 1,30 oraz D - 1,59 i 1,29. Etapowe (obliczane co 7 dni) jak i ww. końcowe wartości FCR i SGR wskazują że przez cały okres badań najkorzystniejsze rezultaty chowu uzyskano żywiąc karpie paszą zawierająca 15,3\% lipidów, bez względu na temperaturę wody pochłodniczej, która w czasie doświadczenia zmieniał́a się w zakresie $22,0-30,0^{\circ} \mathrm{C}$. Wzrastający poziom lipidów w paszach spowodował wzrost wskaźników retencji białka - aNPU (od $24,5 \%$ w wariancie A do $32,3 \%$ w D) i retencji energii - ER (od 29,2\% w A do 53,1\% w D), przy jednoczesnym spadku retencji thuszczu - aLR (od 99,7\% w wariancie A do 46,8\% w D).

Received: 21 May 1998

Author's address:

Jarosław Filipiak PhD DSc

Department of Fisheries Management in Inland Water

Agricultural University of Szczecin

Kazimierza Królewicza 4, 71-550 Szczecin, Poland 